\title{
Drugging the Undruggable using Irreversible Covalent K-Ras G12C Inhibitors
}

\section{K-Ras}

covalent inhibitors

acrylamides

Synthesis of the inhibitor:<smiles>COc1cc(Cl)ccc1[N+](=O)[O-]</smiles><smiles>COc1cc(Cl)c(I)cc1[N+](=O)[O-]</smiles><smiles>COc1cc(Cl)c(I)cc1N</smiles><smiles>CCOC(=O)C=CC#N</smiles>
$29 \%$ yield $95 \%$ yield $88 \%$ yield<smiles>C=CC(=O)N1CCN(C(=O)CNc2cc(I)c(Cl)cc2OC)CC1</smiles><smiles>C=CC(=O)N1CCN(C(=O)CNc2cc(I)c(Cl)cc2O)CC1</smiles><smiles>C=CC(=O)N1CCN(c2nc(=O)n(-c3c(C)ccnc3C(C)C)c3nc(-c4c(O)cccc4F)c(F)cc23)C(C)C1</smiles>

Lumakras, Sotorasib, AMG-510

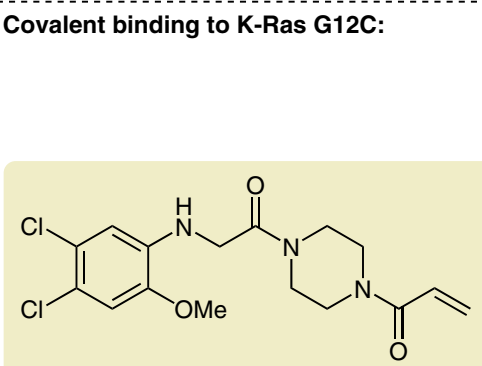

acrylamide analog used for X-ray studies

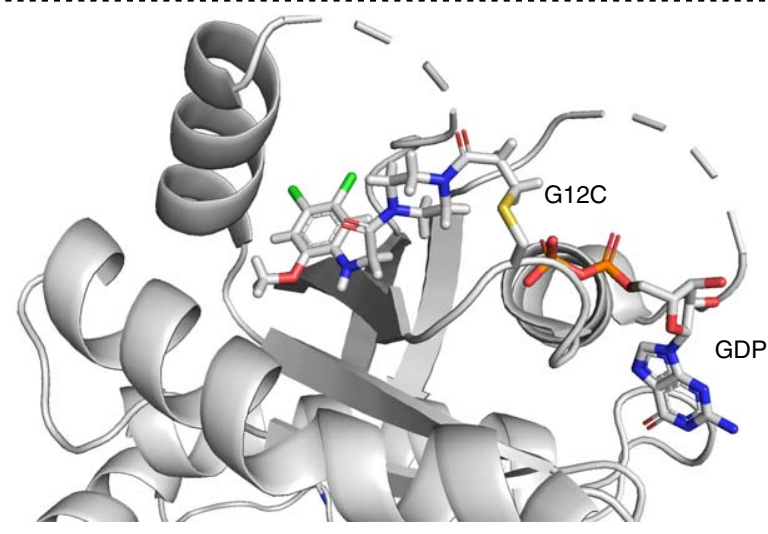

PDB: 4M21

Significance: Mutations in the important regulatory signal transduction protein K-Ras are found in approximately $25 \%$ of human cancers. Attempts to target this notorious GTPase resulted in many failures and the protein became known as 'the undruggable'. Shokat and co-workers took advantage of the nucleophilic cysteine of the $\mathrm{G} 12 \mathrm{C}$ mutant and developed acrylamide-based inhibitors that bind covalently and irreversibly.

SYNFACTS Contributors: Dirk Trauner, Klaus-Peter Ruehmann Synfacts 2021, 17(09), 1055 Published online: 18.08.2021 DOI: 10.1055/s-0040-1720791; Reg-No.: T08121SF
Comment: A library of nearly 500 acrylamides and vinyl sulfonamides was synthesized and tested for K-Ras G12C inhibition. Various aromatic building blocks were combined with the electrophilic portion using amide bond couplings. Based on these discoveries, many companies continued their discovery programs towards K-Ras anticancer drugs. Amgen's Sotorasib became the first FDA-approved K-Ras G12C inhibitor in May 2021. 